\title{
THE RELATIONSHIP BETWEEN RESERVES AND ACCRUALS - WITH REFERENCE TO THE ISSUE OF EARNINGS MANAGEMENT IN PUBLIC COMPANIES
}

\section{Michal Comporek}

University of Lodz, Lodz, Poland

e-mail: michal.comporek@uni.lodz.pl

ORCID: 0000-0002-1402-2505

(C) 2018 Michał Comporek

This is an open access article distributed under the Creative Commons Attribution-NonCommercial-NoDerivs license (http://creativecommons.org/licenses/by-nc-nd/3.0/)

DOI: $10.15611 /$ fins.2018.3.02

JEL Classification: G32, M40

\begin{abstract}
The main objective of the study is to examine the relationship between the implemented reserves policy and the value of accruals reported in the financial statements of public companies listed on the Warsaw Stock Exchange. Both research fields are considered as the main areas of earnings management, which can be seen both as the pursuance of a true and fair view of the economic situation of a business entity and as the intentional manipulation of the results of an economic activity in order to mislead selected stakeholders of company. Empirical studies were conducted among public companies included in the WIG20, mWIG40 and sWIG80 stock indices, whose shares have been traded on the stock market for at least 10 years in the assumed horizon of 1997-2016.
\end{abstract}

Keywords: reserves, provisions, earnings management, accruals, net income.

\section{Introduction}

A company's financial result is one of the most important economic parameters illustrating the effectiveness of undertaken business operations. Its analysis is an important point of reference in assessing: the legitimacy of investing economic resources in the shares of a given enterprise, the degree of multiplying the value of capital contributed by investors and the role and importance of the factors that create value for business unit owners.

The literature of the subject widely emphasizes the fact that due to its complexity and multifaceted nature, the financial result is a highly susceptible category to the shaping process ${ }^{1}$. Its size largely depends on the adopted definition of economic

${ }^{1}$ The earnings management process is difficult to clearly define. In a narrower approach, earnings management occurs when managers use their judgment in financial reporting and in structuring 
events, the concept of capital preservation, methods of valuation of assets and liabilities of the enterprise [Poniatowska 2014, p. 258], as well as on the manner of keeping accounting books, the policy of determining the financial year and its reporting periods, etc. It is noted that the reported amount of financial result in particular segments of its determination is not always only and exclusively the result of the accounting methods and practices used which were adopted by the firm when preparing the financial statements. Often it is also a result of actions aimed at the intentional manipulation of the value of the reported financial profit (or financial loss), inconsistent with the principle of presenting a faithful and reliable image of the entity in the financial statements and not covered by the existing or anticipated economic operations.

The main objective of the article is to characterize the relationships between the policy of creating and terminating reserves and provisions and the values of accruals reported in the financial statements of public companies listed on the Warsaw Stock Exchange. Both the indicated research fields, i.e. the sphere of reserve management and the level of differences between net profit and operational net cash flows are perceived as the main areas of shaping the financial result of the enterprise, which may be aimed at financial results realignment in accordance with the principle of a true and fair view, and takes the form of the deliberate manipulation of financial statement data alike.

Empirical research has been carried out among public companies included in the stock exchange indices: WIG20, mWIG40 and sWIG802, whose shares have been traded for at least ten years with the adopted reference years horizon 1997-2016. The conducted research is based on the information taken from the Notoria Serwis SA database.

\section{Reserves as a tools for shaping a company's financial results}

Article 3, paragraph 1 point 21 of the Polish Accounting Act defines reserves ${ }^{3}$ as liabilities whose maturity date or amount are not certain. They are created in

transactions to alter financial reports to either mislead stakeholders about the underlying economic performance of the company or otherwise to influence contractual outcomes that depend on reported accounting numbers [Healy, Wahlen 1999, p. 368]. This perspective emphasizes the negative aspects of shaping the company's financial result, characterized in the literature as "black earnings management". On the other hand, in a broader approach, earnings management may boil down to the use of flexibility in the selection of accounting solutions that affect the reported result, which may also be positive ("green earnings management") and neutral ("white earnings management") [Smejda 2012, p. 174; Ronen, Yaari 2008, p. 20].

${ }^{2}$ As of October 31, 2017. From the research sample, enterprises conducting economic activity in the finance and insurance sector were excluded.

${ }^{3}$ In Polish legislation, unlike in many other countries, there is no definitive delimitation of the following terms: reserves (which usually are associated with equity as a fraction of retained earnings, which is kept aside for any use in future) and provisions (which are associated with liabilities and un- 
accordance with a legal obligation or a commonly expected commercial obligation, i.e. when there is a high probability that the entity will be required to redeem its obligations. At the same time, the costs or losses required to meet the said obligation would be significant enough that failure to create reserves would cause a significant distortion of the financial position and financial result of the business entity. In addition to the classic accounting reserves, the enterprise in the financial statements also shows any probable amounts of liabilities corresponding to a current reporting period as "passive accruals of cost" (Pol. bierne rozliczenia międzyokresowe kosztów), in particular those resulting from: services performed for an undertaking by its service providers, and the amount of the liability can be reliably estimated as well as an obligation to make future performances to employees, persons unknown etc. [Adamczyk 2017, p. 39].

Due to the financial effect, two main groups of reserves for liabilities can be distinguished, namely cost provisions and provisions resulting in the balance sheet effect. The cost provisions refer to reserves for liabilities due to other operating costs, financial costs or extraordinary losses. They also include provisions for liabilities due to basic operating costs anticipated or incurred to date and provisions created in the burden of income tax charges [Duraj 2008, p. 58]. On the other hand, the provisions that give rise to the balance sheet effect include: reserves causing a decrease in equity and reserves that increase the assets of the enterprise. Eventually, passive accruals of costs are created on account of basic operating activity. They regard expenses incurred in arrears, and therefore those that will be realized in subsequent periods, but which relate to prior periods.

The conscious and deliberate nature of reserves managing takes place not only in the phase of their creation, but also at the stage of their use [Duraj 2008, p. 79]. The creation of reserves, consisting in the appropriate distribution of net profit and its purpose for the implementation of specific goals of the entity, usually occurs in a period in which the financial result is better than expected. This causes decreasing reported financial result of a given accounting year and its "shifting" to later years of worse economic conditions, in which the resolution of reserves will increase the reported financial result [Poniatowska 2014, p. 262]. On the other hand, the reserves underspending results - as the risk that justifies their creation decreases or stops increases other operating income, financial revenues or extraordinary profit of the business entity or their further retention.

derstood as a particular sum of money to cover up an anticipated liability which arises from the past events). In general, both categories are treated as reserves. Discrepancies in this matter arise from the fact that the formal definition of the term 'reserves', narrowing their meaning to the type of obligations, appeared in the provisions of the Accounting Act relatively late, while the term "reserve" functioned in Polish accounting for a long time, however in a different sense. Broadly understood the reserves in this category include: provisions for liabilities, reserves for a loss of value and capital reserves [Poniatowska 2016, p. 70]. For the purposes of the article, provisions are defined as reserves for liabilities, while the term "reserves" is used to determine the remaining other balance sheet reserves. 
The policy of reserves creation does not always have to be aimed at composing a faithful and reliable picture of a company's financial situation. In the business practice of an enterprise, there are common activities related to the creation of fictitious reserves that do not have real justification and falsifying the entity's financial results. Poniatowska [2004, p. 262] notes that the reserves particularly used to manipulate profit are reserves related to the costs of basic operating activity, i.e. passive accruals of cost for warranty repairs (reserves for guarantee repairs) and reserves for retirement benefits. On the other hand, Walińska and Bek-Gaik [2012, pp. 362-363] add that managers can deliberately falsify the value of the financial result by: avoiding creating reserves or formatting excessive reserves, dissolving reserves despite the lack of circumstances justifying their dissolution, resolving reserves contrary to their original purpose and over or undervaluing the amount of reserves. However, it is extremely difficult to determine whether reserves are the subject of the manipulation of the financial result. All the issues of creating and releasing financial reserves by enterprises in a significant way may reflect the strategies of shaping the company's financial result.

In order to achieve the research objective of the paper, six measures were used to assess the dimension of reserves management in public listed companies, namely:

- the coefficient of securing the enterprise with capital reserves $c f s$, showing the share of capital reserves in the total value of equity and foreign capital and adopting the following formula [Duraj, Sosnowski 2015, p. 226]:

$$
c f s=\frac{\operatorname{Prov}_{t}}{T C_{t}}=\frac{S C_{t}+R R_{t}+O \operatorname{OrC}_{t}}{T C_{t}},
$$

where: $c f s \quad-$ coefficient of securing the enterprise with capital reserves;

Prov $_{t}$ - capital financial reserves in year $t$;

$T C_{t}-$ average value of total capital in year $t$;

$S C_{t}-$ average value of registered capital in year $t$;

$R R_{t} \quad$ - average value of supplementary capital in year $t$;

$\mathrm{Orc}_{t}$ - average value of revaluation reserves in year $t$.

- the coefficient of securing the enterprise with balance sheet reserves $f f s$, illustrating the share of the balance sheet reserves in the total value of equity and foreign capital. It has the following form:

$$
f f s=c f s+\frac{\operatorname{ProvD}_{t}}{T C_{t}}=\frac{\operatorname{Prov}_{t}}{T C_{t}}=\frac{S C_{t}+R R_{t}+\operatorname{OrC}_{t}+\operatorname{ProvD}_{t}}{T C_{t}},
$$

where: $f f s \quad-$ coefficient of securing the enterprise with balance sheet reserves;

Prov $_{t}-$ provisions for liabilities in year $t$;

other designations - as above. 
- the coefficient of securing the enterprise with capital reserves in dynamic approach $c f s$, showing the change in the value of capital reserves in the analyzed period in relation to the average value of total capital from the previous period. It is characterized by the following formula [Duraj, Sosnowski 2015, p. 227].

$$
c f s^{\prime}=\frac{\Delta \operatorname{Prov}_{t}}{T C_{t-1}}
$$

where: $c f_{s}{ }^{\prime} \quad-$ coefficient of securing the enterprise with capital reserves in dynamic approach;

$\Delta$ Prov $_{t}$ - change in the value of capital reserves in year $t$; other designations - as above.

- the coefficient of securing the enterprise with balance sheet reserves in dynamic approach $f f s^{\prime}$, illustrating a change in the value of all balance sheet reserves in the period considered in relation to the average value of total capital from the previous period. It has the following form:

$$
f f s^{\prime}=\frac{\Delta \operatorname{Prov}_{t}+\Delta \operatorname{ProvD}_{t}}{T C_{t-1}}
$$

where: $f f s^{\prime} \quad-$ coefficient of securing the enterprise with balance sheet reserves in dynamic approach;

$\operatorname{Prov}_{t}$ - change in the value of provisions for liabilities in year $t$; other designations - as above.

- the reserves relevance coefficient $p d d$, specifying the share of provisions for liabilities in the enterprise's debt, described using this formula [Walińska, Bek-Gaik 2012, p. 363]:

$$
p p d=\frac{\operatorname{Prov} D_{t}}{D_{t}}
$$

where: $p p d \quad-$ reserves relevance coefficient;

$D_{t} \quad-$ average value of total liabilities in year $t$;

other designations - as above.

- the coefficient of impact of change in the value of provisions for liabilities on company's net income ${ }^{4} p d e$ ', calculated as follows:

${ }^{4}$ It should be noted here that the change in provisions for liabilities is one of the items of adjustments in Part A of the cash flow statement prepared using the indirect method. It is determined as a change in balance sheet liabilities, although this item cannot always be directly transferred from the balance sheet, because deferred tax provisions can be settled with equity and then do not affect the entity's financial result [Zbaraszewska 2011, p. 704]. 


$$
p d e^{\prime}=\frac{\operatorname{ProvD}_{O C F t}}{E A T_{t}},
$$

where: $p d e^{\prime} \quad-$ coefficient of impact of change in the value of provisions for liabilities on company's net income;

Prov $D_{O C F t}-\begin{aligned} & \text { change in the value of provisions for liabilities (shown in } \\ & \text { the cash flow statement) in year } t \text {; }\end{aligned}$

$E A T_{t} \quad-$ earnings after taxes in year $t$; other designations - as above.

\section{Accruals as a tool for shaping a company's financial results}

Accruals, shown in the cash flow statement using the indirect method, can be characterized from different viewpoints. Their primary goal is to "bring down" the memorial (or accrual-based) value of net income to its cash value. However, it is not only an accounting transformation of financial data for the needs of cash flow statement preparation and its use in assessing the effectiveness of the company's operations. The values of accruals reflected among others: all changes in the states of basic components of current assets, short-term liabilities and provisions for liabilities, which gives the opportunity to fully recognize and assess the reliability of the financial situation of the company [Comporek 2016, p. 137].

The amount of total accruals $T A C C$ is the difference between the net income in a given year computed by using an accrual-based accounting system and the surplus in cash from operating activities. Its value arises as a result of the accrualbasis record of all non-cash and cash economic events, which allows management a certain degree of freedom in the subjective creation of an image of the company's financial result. This can be represented by the following equation:

$$
T A C C_{t}=E A T_{t}-O C F_{t},
$$

where: $T A C C_{t}-$ total accruals in year $t$;

$O C F_{t}$ - operating cash flows in year $t$;

other designations - as above.

At the same time it should be remembered that the composition of total accruals includes both non-discretionary (operational) accruals $N D A C C$, as well as discretionary (intentional) accruals $D A C C$. Operational accruals relate strictly to the real sphere of the company's operations. They refer to the economic operations actually occurring in a given accounting year, which from the point of view of accounting principles can be included as one of the following items: amortization and depreciation, exchange gains (losses), interest and profit sharing, profit (loss) on investment activities or changes in provisions, inventories, receivables, short-term 
liabilities excluding credits and loans, prepayments etc. Intentional accruals, on the other hand, do not depend on the nature and size of the business. They constitute a summary result of activities aimed at deliberately lowering the transparency of financial statements, in accordance with the assumptions of the so-called "black earnings management" [Arkan 2015, p. 250].

The interpretation and assessment of the scale of the earnings management phenomenon in an economic entity significantly depend on the ability to accurately analyze the accrual adjustments of net profit, taking into account both operating and intentional accruals [Dechow, Skinner 2000, pp. 235-250]. In the most common research approaches used in the literature, the regression models describing the value of the TACC are used to separate particular categories of accruals. In order to achieve the set aim of this study, three models were used for the diagnostic calculation of operational and intentional values of accrual differences, namely: the Jones model, the Jones model with the ROA coefficient as the predictor and the Kasznik model ${ }^{5}$.

The Jones model assumes that the value of operational accruals is determined by two variables: change in sales revenues and average value of property, plant and equipment [Jones 1991, pp. 193-228]. In turn, the value of intentional accruals is based on the difference between the empirical and theoretical value of the TACC as the explained variable. Seeing that the value of intentional accruals can be calculated as:

$$
T A C C_{t}=N D A C C_{t}+D A C C_{t},
$$

where: $N D A C C_{t}-$ total accruals in year $t$;

$D A C C_{t}$ - discretionary accruals in year $t$;

other designations - as above.

and at the same time:

$$
\operatorname{TACC}_{t}=\alpha_{0}+\alpha_{1} X_{N D A C C 1, t}+\alpha_{2} X_{N D A C C 2, t}+\ldots+\alpha_{k} X_{N D A C C k, t}+\varepsilon_{t},
$$

where: $T A C C_{t} \quad$ - dependent (response) variable;

$\alpha_{1} \quad-$ regression parameter;

$X_{N D A C C l, t}$ - explanatory variable;

$\varepsilon_{t} \quad-$ error term in regression.

\footnotetext{
${ }^{5}$ The literature on the subject demonstrates more references to total accruals models that allow the extraction of individual sub-categories of total accruals. Apart from the ones mentioned in the text of the article, models particularly emphasized in the literature are: the Healy model, the DeAngelo model, the Dechow et al. model, and the Kang and Sivaramakrishnan model (see: [Healy 1985, pp. 87-105; DeAngelo 1986, pp. 400-420; Dechow et. al. 1995, pp.193-225; Kang, Sivaramakrishnan 1995, pp. 353-367]).
} 
therefore, the Jones model will be characterized by the following calculation formula

$$
\underbrace{\frac{T A C C_{t}}{T A_{t-1}}=\alpha_{1}\left(\frac{1}{T A_{t-1}}\right)+\alpha_{2}\left(\frac{\Delta R E V_{t}}{T A_{t-1}}\right)+\alpha_{3}\left(\frac{P P E_{t}}{T A_{t-1}}\right)}_{\begin{array}{c}
\text { non-discretionary accruals } \\
N D A C C_{\text {Jones }}
\end{array}}+\underbrace{\varepsilon_{t}}_{\begin{array}{c}
\text { discretionary accruals } \\
\text { DACC } C_{\text {Jones }}
\end{array}}
$$

where: $T A_{t-1} \quad-$ average value of total assets from year $t-1$;

$\triangle R E V_{t} \quad$ - change in sales revenues in year $t$;

$P P E_{t} \quad$ - average value of property, plant and equipment in year $t$; other designations - as above.

The modified version of the Jones model, developed by Kothari, Leone and Wesley, assumes that one of the variables explaining the level of total accruals TACC is the ROA coefficient. In this way, the form of the regression model, allowing the separation of individual categories of accrual differences, took the following form [Kothari et al. 2005, pp. 163-197]:

$$
\frac{T A C C_{t}}{T A_{t-1}}=\underbrace{\alpha_{1}\left(\frac{1}{T A_{t-1}}\right)+\alpha_{2}\left(\frac{\Delta R E V_{t}}{T A_{t-1}}\right)+\alpha_{3}\left(\frac{P P E_{t}}{T A_{t-1}}\right)+\alpha_{4} R O A_{t}}_{\begin{array}{c}
\text { non-discretionary accruals } \\
N D A C C_{\text {Jones } R O A}
\end{array}}+\underbrace{+\varepsilon_{t}}_{\begin{array}{c}
\text { discretionary } \\
\text { accruals } D A C C_{\text {Jones }}
\end{array}}
$$

where: $R O A_{t} \quad-$ return on assets coefficient in year $t$;

other designations - as above.

In turn, in the Kashnik model, any changes in the operational part of total accruals are explained by using such predicators as: the difference between change in sales revenues and change in short-term receivables, the average value of property, plant and equipment and the increase in operating cash flows [Kasznik 1999, pp. 57-81]. The regressive model adopts the following formula:

${ }^{6}$ Assuming that large enterprises will show higher values of accruals, in order to obtain data comparability (and at the same time eliminate potential heteroskedasticity), all models used to distinguish operational and intentional components of accruals were standardized by including in the calculation formula a variable representing the value of total assets from the previous year $\left(T A_{t-1}\right)$. 


$$
\begin{aligned}
& \frac{T A C C_{t}}{T A_{t-1}}=\alpha_{1}\left(\frac{1}{T A_{t-1}}\right)+\alpha_{2}\left(\frac{\Delta R E V_{t}-\Delta R E C_{t}}{T A_{t-1}}\right)+\alpha_{3}\left(\frac{P P E_{t}}{T A_{t-1}}\right)+\alpha_{4}\left(\frac{\Delta O C F_{t}}{T A_{t-1}}\right)+\varepsilon_{t}, \\
& \underbrace{\underbrace{}_{r}} \\
& \text { non-discretionary } \\
& \text { accruals NDACC Kasznik }
\end{aligned}
$$

where: $\triangle R E C_{t} \quad$ - change in trade receivables in year $t$;

$\triangle O C F_{t}$ - change in operation cash flow in year $t$ relative to year $t-1$; other designations - as above.

\section{Results of empirical research concerning the relation between financial reserves and accruals in public listed companies}

The basic empirical examinations have been focused around the values of correlations calculated by the Pearson correlation coefficient. This measure was used to compute the intensity and direction of the relationships between the six financial reserve policy ratios (described in the second chapter of the article) and the relative value of operational and intentional accruals separated by: the Jones model, the Jones model with ROA as predictor of TACC and the Kasznik model.

The results of the correlation analysis carried out for all the analyzed listed companies indicate that the relations between the implemented reserve management policy and the operational accruals have a different strength ${ }^{7}$ (see Table 2). Clear linear correlations reported in the case of the relationship between the ratio of securing the enterprise with capital reserves in dynamic approach $c f s$ ' and operational accruals calculated using the Jones model and the Kasznik model and between the coefficient of securing the enterprise with balance sheet reserves in dynamic approach $f f s$ ' and the operational differences on the accruals separated using both mentioned models. The strength of the presented relationship, measured by the Pearson's linear correlation coefficient, ranged from $21.4 \%-25.3 \%$. In turn, statistically significant correlations - however with very low power - have been proved in five other relationships.

${ }^{7}$ In the article the following interpretation of the calculated correlation coefficients should be adopted, namely:

- $\mathrm{r}=0-$ no correlation,

- $0<|\mathrm{r}|<0.2$ - practically no linear correlation between the examined variables,

- $0,2 \leq|\mathrm{r}|<0.4$ - linear correlation clear, but low,

- $0,4 \leq|\mathrm{r}|<0.7$ - moderate correlation,

- $0,7 \leq|\mathrm{r}|<0.9$ - significant correlation,

- $|\mathrm{r}| \geq 0.9$ - correlation very strong,

- $|\mathrm{r}|=1$ - full correlation [Ostasiewicz, Rusnak, Siedlecka 2001, p. 311]. 
In-depth empirical studies on the relationships occurring between the analyzed variables in public enterprises belonging to particular sector indices indicate the existence of differences in the nature and strength of the tested correlations (see Table 1). In generalized terms, the most frequently observed statistically significant relationships include the relationships between operational accruals and the $c f s^{\prime}$ and $f f s^{\prime}$ reserve management ratios. At the same time, in the companies belonging to the WIG-Media index, the relationships between the discussed variables were able to take the form of significant negative correlations. It should also be noted that the change in the ratio of the impact of provisions for liabilities on company's net income pde' was in the smallest extent correlated with the non-discretionary accruals.

Table 1. Relationship between non-discretionary (operational) accruals and reserves management policy ratios investigated by using the Pearson linear correlation coefficient

\begin{tabular}{|c|c|c|c|c|c|}
\hline \multirow{2}{*}{$\begin{array}{l}\text { Main indices } \\
\text { (sector indices) }\end{array}$} & \multirow{2}{*}{$\begin{array}{c}\text { Measure } \\
\text { of reserves } \\
\text { management }\end{array}$} & \multicolumn{3}{|c|}{ A model for extracting operational accruals } & \multirow{2}{*}{$\begin{array}{c}\text { No. of } \\
\text { observations }\end{array}$} \\
\hline & & $\mathrm{NDACC}_{\text {Jones }}$ & $\mathrm{NDACC}_{\text {Jones ROA }}$ & NDACC $_{\text {Kasznik }}$ & \\
\hline 1 & 2 & 3 & 4 & 5 & 6 \\
\hline \multirow{6}{*}{$\begin{array}{l}\text { WIG20 } \\
+ \\
\text { mWIG40 } \\
+ \\
\text { sWIG80 }\end{array}$} & cfs & 0.011 & -0.012 & 0.032 & \multirow{6}{*}{1306} \\
\hline & ffs & -0.011 & -0.034 & 0.029 & \\
\hline & cfs' & $0.253 * *$ & $0.180 * *$ & $0.222 * *$ & \\
\hline & ffs' & $0.248 * *$ & $0.168 * *$ & $0.214 * *$ & \\
\hline & ppd & $-0.138 * *$ & $-0.090 * *$ & $-0.098 * *$ & \\
\hline & ppe' & 0.004 & 0.004 & 0.022 & \\
\hline \multirow{6}{*}{$\begin{array}{l}\text { WIG-budownictwo } \\
\text { (architecture) }\end{array}$} & $\mathrm{cfs}$ & $-0.232 * *$ & $0.175 *$ & 0.034 & \multirow{6}{*}{167} \\
\hline & $\mathrm{ffs}$ & $-0.269 *$ & 0.110 & 0.014 & \\
\hline & cfs' & 0.150 & $0.226 *$ & 0.143 & \\
\hline & ffs' & 0.120 & -0.006 & 0.062 & \\
\hline & ppd & $-0.316 * *$ & $-0.330 * *$ & $-0.174 *$ & \\
\hline & ppe' & -0.012 & -0.018 & 0.004 & \\
\hline \multirow{6}{*}{$\begin{array}{l}\text { WIG-chemia } \\
\text { (chemicals) }\end{array}$} & $\mathrm{cfs}$ & $0.338 *$ & -0.036 & $0.331 *$ & \multirow{6}{*}{56} \\
\hline & $\mathrm{ffs}$ & $0.284 *$ & -0.103 & $0.299 *$ & \\
\hline & cfs' & -0.118 & $-0.285 *$ & -0.010 & \\
\hline & ffs' & -0.131 & $-0.276 *$ & -0.011 & \\
\hline & ppd & $-0.302 *$ & $-0.274^{*}$ & -0.232 & \\
\hline & ppe' & -0.073 & -0.107 & -0.043 & \\
\hline \multirow{6}{*}{$\begin{array}{l}\text { WIG-energia } \\
\text { (energy) }\end{array}$} & $\mathrm{cfs}$ & $0.411 *$ & $0.318 *$ & $0.397 * *$ & \multirow{6}{*}{56} \\
\hline & ffs & $0.366 \%$ & $0.274 *$ & $0.353 * *$ & \\
\hline & cfs' & -0.121 & -0.068 & -0.138 & \\
\hline & ffs' & -0.140 & -0.095 & -0.121 & \\
\hline & ppd & $-0.428 * *$ & $-0.291 *$ & $-0.419 * *$ & \\
\hline & ppe' & 0.162 & 0.106 & 0.147 & \\
\hline
\end{tabular}


The relationship between reserves and accruals - with reference to the issue...

\begin{tabular}{|c|c|c|c|c|c|}
\hline 1 & 2 & 3 & 4 & 5 & 6 \\
\hline \multirow{6}{*}{$\begin{array}{l}\text { WIG-górnictwo } \\
\text { (mining) }\end{array}$} & $\mathrm{cfs}$ & $-0.412 * *$ & $-0.464 * *$ & -0.272 & \multirow{6}{*}{29} \\
\hline & ffs & $-0.400 * *$ & $-0.424 * *$ & -0.288 & \\
\hline & cfs' & -0.070 & -0.192 & 0.147 & \\
\hline & ffs' & -0.115 & -0.216 & 0.088 & \\
\hline & ppd & 0.012 & 0.215 & 0.008 & \\
\hline & ppe' & 0.028 & 0.251 & -0.023 & \\
\hline \multirow{6}{*}{$\begin{array}{l}\text { WIG-informatyka } \\
\text { (informatics) }\end{array}$} & $\mathrm{cfs}$ & 0.013 & -0.127 & -0.026 & \multirow{6}{*}{60} \\
\hline & ffs & 0.013 & -0.132 & -0.026 & \\
\hline & cfs' & $0.563^{* * *}$ & $0.406 * *$ & $0.313 * *$ & \\
\hline & ffs' & $0.564 * *$ & $0.407 * *$ & 0.313 ** & \\
\hline & ppd & -0.071 & -0.172 & -0.067 & \\
\hline & ppe' & -0.117 & -0.015 & 0.187 & \\
\hline \multirow{6}{*}{$\begin{array}{l}\text { WIG-leki } \\
\text { (pharmaceutical) }\end{array}$} & $\mathrm{cfs}$ & 0.331* & 0.226 & 0.273 & \multirow{6}{*}{38} \\
\hline & ffs & 0.311 & 0.213 & 0.278 & \\
\hline & cfs' & $0.691 * *$ & $0.690 * *$ & $0.687 * *$ & \\
\hline & ffs' & $0.696^{* * *}$ & $0.698^{* * *}$ & 0.690 ** & \\
\hline & ppd & -0.083 & -0.003 & -0.060 & \\
\hline & ppe' & 0.120 & 0.127 & 0.105 & \\
\hline \multirow{6}{*}{$\begin{array}{l}\text { WIG-media } \\
\text { (media) }\end{array}$} & $\mathrm{cfs}$ & $-0.588 * *$ & $-0.606 * *$ & $-0.579 * *$ & \multirow{6}{*}{19} \\
\hline & ffs & $-0.568 * *$ & $-0.598 * *$ & $-0.588^{* *}$ & \\
\hline & $\mathrm{cfs}^{\prime}$ & $-0.682 * *$ & $-0.590 * *$ & $-0.709 * *$ & \\
\hline & ffs' & $-0.710 * *$ & $-0.605 * *$ & $-0.729 * *$ & \\
\hline & ppd & 0.438 & 0.415 & 0.455 & \\
\hline & ppe' & 0.107 & 0.114 & 0.086 & \\
\hline \multirow{6}{*}{$\begin{array}{l}\text { WIG-motoryzacja } \\
\text { (automotive) }\end{array}$} & $\mathrm{cfs}$ & $-0.285^{*}$ & $-0.468 * *$ & -0.211 & \multirow{6}{*}{72} \\
\hline & ffs & $-0.387 * *$ & $-0.531 * *$ & $-0.280^{*}$ & \\
\hline & cfs' & 0.171 & $0.250 *$ & 0.119 & \\
\hline & ffs' & 0.173 & $0.248^{*}$ & 0.118 & \\
\hline & ppd & $-0.597 * *$ & $-0.440 * *$ & $-0.533 * *$ & \\
\hline & ppe' & -0.042 & 0.015 & -0.027 & \\
\hline \multirow{6}{*}{$\begin{array}{l}\text { WIG-nieruchomości } \\
\text { (real estate ) }\end{array}$} & $\mathrm{cfs}$ & -0.094 & -0.110 & -0.099 & \multirow{6}{*}{100} \\
\hline & $\mathrm{ffs}$ & -0.064 & -0.115 & -0.073 & \\
\hline & cfs' & 0.080 & 0.027 & 0.034 & \\
\hline & ffs' & 0.089 & 0.025 & 0.039 & \\
\hline & ppd & 0.085 & 0.074 & 0.088 & \\
\hline & ppe' & 0.160 & 0.062 & 0.056 & \\
\hline \multirow{6}{*}{$\begin{array}{l}\text { WIG-odzież } \\
\text { (clothing) }\end{array}$} & $\mathrm{cfs}$ & 0.061 & -0.003 & 0.063 & \multirow{6}{*}{85} \\
\hline & ffs & 0.050 & -0.008 & 0.058 & \\
\hline & cfs' & $0.371 * *$ & 0.133 & $0.334 * *$ & \\
\hline & ffs' & $0.372 * *$ & 0.132 & $0.333^{* * *}$ & \\
\hline & ppd & $-0.273^{*}$ & $-0.342 * *$ & -0.146 & \\
\hline & ppe' & -0.111 & -0.028 & 0.036 & \\
\hline
\end{tabular}


Table 1, cont.

\begin{tabular}{|c|c|c|c|c|c|}
\hline 1 & 2 & 3 & 4 & 5 & 6 \\
\hline \multirow{6}{*}{$\begin{array}{l}\text { WIG-paliwa } \\
\text { (fuel sector) }\end{array}$} & $\mathrm{cfs}$ & 0.021 & -0.041 & -0.057 & \multirow{6}{*}{49} \\
\hline & ffs & -0.011 & -0.023 & -0.128 & \\
\hline & cfs' & 0.205 & -0.046 & 0.140 & \\
\hline & ffs' & 0.204 & -0.050 & 0.144 & \\
\hline & ppd & -0.129 & 0.187 & -0.161 & \\
\hline & ppe' & -0.021 & 0.089 & 0.024 & \\
\hline \multirow{6}{*}{$\begin{array}{l}\text { WIG-spożywczy } \\
\text { (food) }\end{array}$} & $\mathrm{cfs}$ & $-0.412 * *$ & -0.227 & -0.248 & \multirow{6}{*}{42} \\
\hline & ffs & $-0.397 * *$ & -0.207 & -0.236 & \\
\hline & cfs' & $0.327 *$ & $0.373 *$ & $0.543 * *$ & \\
\hline & ffs' & $0.342 *$ & $0.392 *$ & $0.546 * *$ & \\
\hline & ppd & -0.006 & 0.017 & 0.062 & \\
\hline & ppe' & -0.063 & -0.056 & 0.124 & \\
\hline \multirow{6}{*}{$\begin{array}{l}\text { WIG- } \\
\text { telekomunikacja } \\
\text { (telecommunication) }\end{array}$} & $\mathrm{cfs}$ & 0.123 & $-0.548 * *$ & 0.115 & \multirow{6}{*}{50} \\
\hline & ffs & 0.129 & $-0.552 * *$ & 0.122 & \\
\hline & cfs' & -0.186 & $-0.390 * *$ & -0.184 & \\
\hline & ffs' & -0.181 & $-0.379 * *$ & -0.181 & \\
\hline & ppd & 0.035 & $-0.412 * *$ & 0.053 & \\
\hline & ppe' & 0.124 & 0.052 & 0.112 & \\
\hline \multirow{6}{*}{$\begin{array}{l}\text { Stock exchange } \\
\text { companies not } \\
\text { belonging to the } \\
\text { mentioned sector } \\
\text { indices }\end{array}$} & $\mathrm{cfs}$ & 0.025 & -0.001 & 0.023 & \multirow{6}{*}{483} \\
\hline & ffs & 0.016 & -0.009 & 0.018 & \\
\hline & cfs' & $0.280 * *$ & $0.230 * *$ & $0.236^{* *}$ & \\
\hline & ffs' & $0.281 * *$ & $0.231 * *$ & $0.233 * *$ & \\
\hline & ppd & 0.013 & 0.093* & 0.054 & \\
\hline & ppe' & -0.015 & -0.017 & -0.068 & \\
\hline
\end{tabular}

The bold font indicates correlations that are statistically significant, where: * statistically significant correlations with the assumed significance level $\alpha=0.05 ; * *$ statistically significant correlations with the assumed significance level $\alpha=0.01$.

Source: own study based on financial information from the Notoria Serwis SA database.

Further analysis of Table 2 indicates several other findings worthy of comment.

It should be emphasized that in the entire surveyed group of enterprises there were statistically significant relationships (with at least moderate power, $\mid r>0.4$ ) between the analyzed measures of managing a company's reserves and intentional accruals (see Table 2). However, the nature of these relations is clearly differentiated due to the specificity of the undertaken business activity. For example, the presence of moderate positive correlations between the $c f s$ ' and $f f s$ ' ratios and the discretionary accruals $D A C C$ was recorded in the groups of listed companies classified into the following indices: WIG-mining, WIG-pharmaceutical, WIG-food. On the other hand, statistically significant moderate negative relations between analyzed measures of the policy of creating and dissolving reserves and intentional accruals have been captured in relation to entities belonging to subindices: WIG-automotive and WIG- 
-telecommunication. This leads to the conclusion that reserve management policy can shape the level of earnings management in various ways.

Table 2. Relationship between discretionary (intentional) accruals and reserves management policy ratios investigated by using the Pearson linear correlation coefficient

\begin{tabular}{|c|c|c|c|c|c|}
\hline \multirow{2}{*}{$\begin{array}{l}\text { Main indices } \\
\text { (sector indices) }\end{array}$} & \multirow{2}{*}{$\begin{array}{c}\text { Measure } \\
\text { of reserves } \\
\text { management }\end{array}$} & \multicolumn{3}{|c|}{ A model for extracting intentional accruals } & \multirow{2}{*}{$\begin{array}{c}\text { No. of } \\
\text { observations }\end{array}$} \\
\hline & & DACC $_{\text {Jones }}$ & $\mathrm{DACC}_{\text {Jones ROA }}$ & $\mathrm{DACC}_{\text {Kasznik }}$ & \\
\hline 1 & 2 & 3 & 4 & 5 & 6 \\
\hline \multirow{6}{*}{$\begin{array}{l}\text { WIG20 } \\
+ \\
\text { mWIG40 } \\
+ \\
\text { sWIG80 }\end{array}$} & Cfs & -0.006 & 0.025 & -0.037 & \multirow{6}{*}{1306} \\
\hline & Ffs & 0.011 & 0.028 & -0.047 & \\
\hline & cfs' & $0.097 * *$ & $0.147 * *$ & $0.096 * *$ & \\
\hline & ffs' & $0.086 * *$ & $0.136 *$ & $0.086 * *$ & \\
\hline & Ppd & 0.011 & 0.014 & -0.022 & \\
\hline & ppe' & 0.024 & 0.037 & 0.007 & \\
\hline \multirow{6}{*}{$\begin{array}{l}\text { WIG-budownictwo } \\
\text { (architecture) }\end{array}$} & Cfs & $0.356 * *$ & $0.185 *$ & $0.298 * *$ & \multirow{6}{*}{167} \\
\hline & Ffs & $0.297 * *$ & $0.173 *$ & $0.217 * *$ & \\
\hline & cfs' & $0.173 *$ & 0.099 & $0.195 *$ & \\
\hline & ffs' & 0.009 & 0.045 & 0.014 & \\
\hline & Ppd & -0.084 & 0.065 & -0.153 & \\
\hline & ppe' & 0.012 & 0.006 & 0.019 & \\
\hline \multirow{6}{*}{$\begin{array}{l}\text { WIG-chemia } \\
\text { (chemicals) }\end{array}$} & $\mathrm{Cfs}$ & -0.220 & 0.075 & $-0.364 * *$ & \multirow{6}{*}{56} \\
\hline & Ffs & -0.222 & 0.098 & $-0.388 * *$ & \\
\hline & cfs' & -0.213 & -0.018 & $-0.360 * *$ & \\
\hline & ffs' & -0.182 & -0.002 & $-0.325 *$ & \\
\hline & Ppd & 0.018 & 0.096 & 0.002 & \\
\hline & ppe' & 0.053 & 0.116 & 0.029 & \\
\hline \multirow{6}{*}{$\begin{array}{l}\text { WIG-energia } \\
\text { (energy) }\end{array}$} & Cfs & 0.032 & 0.023 & 0.024 & \multirow{6}{*}{56} \\
\hline & Ffs & 0.018 & 0.038 & 0.011 & \\
\hline & cfs' & 0.025 & 0.017 & 0.047 & \\
\hline & ffs' & 0.037 & 0.052 & 0.033 & \\
\hline & Ppd & 0.077 & 0.033 & 0.095 & \\
\hline & ppe' & -0.008 & -0.068 & 0.001 & \\
\hline \multirow{6}{*}{$\begin{array}{l}\text { WIG-górnictwo } \\
\text { (mining) }\end{array}$} & Cfs & -0.077 & 0.280 & -0.153 & \multirow{6}{*}{29} \\
\hline & Ffs & -0.090 & 0.257 & -0.117 & \\
\hline & cfs' & 0.121 & $0.488 * *$ & -0.048 & \\
\hline & ffs' & 0.142 & $0.502 * *$ & -0.012 & \\
\hline & Ppd & 0.253 & 0.057 & 0.208 & \\
\hline & ppe' & 0.245 & 0.007 & 0.319 & \\
\hline \multirow{6}{*}{$\begin{array}{l}\text { WIG-informatyka } \\
\text { (informatics) }\end{array}$} & Cfs & -0.183 & -0.065 & -0.208 & \multirow{6}{*}{60} \\
\hline & Ffs & -0.186 & -0.066 & -0.212 & \\
\hline & cfs' & 0.097 & 0.129 & $0.274 *$ & \\
\hline & ffs' & 0.096 & 0.132 & $0.274 *$ & \\
\hline & Ppd & -0.118 & 0.029 & -0.158 & \\
\hline & ppe' & 0.107 & 0.011 & -0.224 & \\
\hline
\end{tabular}


Table 2, cont.

\begin{tabular}{|c|c|c|c|c|c|}
\hline 1 & 2 & 3 & 4 & 5 & 6 \\
\hline \multirow{6}{*}{$\begin{array}{l}\text { WIG-leki } \\
\text { (pharmaceutical) }\end{array}$} & $\mathrm{Cfs}$ & 0.034 & 0.172 & 0.045 & \multirow{6}{*}{38} \\
\hline & Ffs & 0.046 & 0.178 & 0.056 & \\
\hline & cfs' & $0.415 * *$ & $0.402 * *$ & $0.428 * *$ & \\
\hline & ffs' & $0.418 * *$ & $0.397 * *$ & $0.438 * *$ & \\
\hline & Ppd & 0.225 & 0.170 & 0.290 & \\
\hline & ppe' & 0.052 & 0.019 & 0.059 & \\
\hline \multirow{6}{*}{$\begin{array}{l}\text { WIG-media } \\
\text { (media) }\end{array}$} & Cfs & -0.039 & -0.013 & -0.045 & \multirow{6}{*}{19} \\
\hline & Ffs & -0.063 & -0.035 & -0.070 & \\
\hline & cfs' & -0.070 & -0.048 & -0.100 & \\
\hline & ffs' & -0.073 & -0.048 & -0.104 & \\
\hline & Ppd & -0.163 & -0.126 & -0.104 & \\
\hline & ppe' & 0.255 & 0.145 & 0.265 & \\
\hline \multirow{6}{*}{$\begin{array}{l}\text { WIG-motoryzacja } \\
\text { (automotive) }\end{array}$} & Cfs & $-0.323 * *$ & -0.085 & $-0.428 * *$ & \multirow{6}{*}{72} \\
\hline & Ffs & $-0.327 * *$ & -0.090 & $-0.424 * *$ & \\
\hline & cfs' & 0.110 & 0.022 & 0.162 & \\
\hline & ffs' & 0.123 & 0.013 & 0.168 & \\
\hline & Ppd & -0.061 & -0.087 & 0.011 & \\
\hline & ppe' & 0.072 & 0.113 & 0.015 & \\
\hline \multirow{6}{*}{$\begin{array}{l}\text { WIG-nieruchomości } \\
\text { (real estate) }\end{array}$} & Cfs & -0.051 & 0.099 & -0.042 & \multirow{6}{*}{110} \\
\hline & Ffs & -0.066 & 0.101 & -0.059 & \\
\hline & cfs' & 0.089 & $0.308 * *$ & 0.108 & \\
\hline & ffs' & 0.083 & $0.305 * *$ & 0.102 & \\
\hline & Ppd & -0.067 & 0.107 & -0.075 & \\
\hline & ppe' & 0.019 & 0.055 & 0.055 & \\
\hline \multirow{6}{*}{$\begin{array}{l}\text { WIG-odzież } \\
\text { (clothing) }\end{array}$} & Cfs & 0.007 & 0.051 & -0.002 & \multirow{6}{*}{85} \\
\hline & Ffs & 0.008 & 0.061 & -0.001 & \\
\hline & cfs' & 0.115 & $0.270 *$ & 0.070 & \\
\hline & ffs' & 0.119 & $0.275^{*}$ & 0.074 & \\
\hline & Ppd & -0.131 & 0.085 & -0.185 & \\
\hline & ppe' & 0.061 & 0.059 & 0.015 & \\
\hline \multirow{6}{*}{$\begin{array}{l}\text { WIG-paliwa } \\
\text { (fuel sector) }\end{array}$} & Cfs & -0.198 & -0.211 & -0.158 & \multirow{6}{*}{49} \\
\hline & Ffs & -0.168 & -0.215 & -0.131 & \\
\hline & cfs' & -0.191 & -0.068 & -0.149 & \\
\hline & ffs' & -0.171 & -0.068 & -0.137 & \\
\hline & Ppd & 0.232 & 0.018 & 0.247 & \\
\hline & ppe' & 0.082 & -0.010 & 0.072 & \\
\hline \multirow{6}{*}{$\begin{array}{l}\text { WIG-spożywczy } \\
(\text { food })\end{array}$} & Cfs & 0.043 & -0.084 & -0.020 & \multirow{6}{*}{42} \\
\hline & Ffs & 0.053 & -0.079 & -0.028 & \\
\hline & cfs' & $0.416 * *$ & $0.370 *$ & 0.159 & \\
\hline & ffs' & $0.432 * *$ & $0.379 *$ & 0.147 & \\
\hline & Ppd & 0.119 & 0.097 & 0.045 & \\
\hline & ppe' & $0.307 *$ & $0.345 *$ & 0.180 & \\
\hline
\end{tabular}




\begin{tabular}{|c|c|c|c|c|c|}
\hline 1 & 2 & 3 & 4 & 5 & 6 \\
\hline \multirow{6}{*}{$\begin{array}{l}\text { WIG- } \\
\text { telekomunikacja } \\
\text { (telecommunication) }\end{array}$} & $\mathrm{Cfs}$ & $-0.569 * *$ & 0.037 & $-0.590 * *$ & \multirow{6}{*}{50} \\
\hline & Ffs & $-0.576 * *$ & 0.034 & $-0.598 * *$ & \\
\hline & cfs' & $-0.412 * *$ & -0.272 & $-0.424 * *$ & \\
\hline & ffs' & $-0.410 * *$ & -0.271 & $-0.415^{* * *}$ & \\
\hline & Ppd & $-0.359 *$ & 0.118 & $-0.381 * *$ & \\
\hline & ppe' & -0.171 & -0.129 & -0.177 & \\
\hline \multirow{6}{*}{$\begin{array}{l}\text { Stock exchange } \\
\text { companies not } \\
\text { belonging to the } \\
\text { mentioned sector } \\
\text { indices }\end{array}$} & $\mathrm{Cfs}$ & -0.043 & -0.035 & -0.046 & \multirow{6}{*}{483} \\
\hline & Ffs & -0.044 & -0.033 & -0.053 & \\
\hline & cfs' & 0.135* & $0.156 *$ & $0.143^{*}$ & \\
\hline & ffs' & 0.136* & $0.154 *$ & $0.147 *$ & \\
\hline & Ppd & 0.060 & -0.046 & 0.028 & \\
\hline & ppe' & -0.071 & $-0.101 *$ & -0.021 & \\
\hline
\end{tabular}

The bold font indicates correlations that are statistically significant, where: * statistically significant correlations with the assumed significance level $\alpha=0.05 ; * *$ statistically significant correlations with the assumed significance level $\alpha=0.01$.

Source: own study based on financial information from the Notoria Serwis SA database.

\section{Conclusions}

The shaping of a company's financial results may take various forms. This is a result of both the accrual accounting practice applied, having its expression in accounting choices (including also the issue of creating provisions for liabilities and passive accruals of cost and other reserves) as well as the result of ongoing economic operations reflected among others in accruals. Despite numerous legislative conditions, economic entities have a fairly large area of freedom as regards the pursued policy of managing reserves and accrual records of all non-cash and cash economic events. As a result, these spheres of earnings management are often used to manipulate and falsify the reported financial results.

The results of the empirical studies presented in the article show that a company's reserves are a slightly more correlated with the category of operational accruals than with their intentional counterparts. From the perspective of the whole researched population, special attention should be directed to the correlation between the coefficients of securing the enterprise with capital and balance sheet reserves in dynamic terms ( $c f s^{\prime}$ ' and $f f s^{\prime}$ ' respectively) and two subcategories of company accruals (operational and intentional accruals), because they are characterized by the highest dependence power. The in-depth empirical analysis also showed significant fluctuations in the strength and direction of the relationship between the variables under study, depending on the nature of the business undertaken.

The presented test results cannot fulfil the condition of generalization for at least two reasons. First of all, they contain partial results, opening up prospects for further 
research on the determinants of profit management and their mutual relations. Secondly, the regression models used in the analysis allow only an estimation of the value of the individual categories of accruals ${ }^{8}$. It seems, however, that they strengthen the existing results of empirical research on the phenomenon of management earnings in public enterprises in Poland.

\section{Bibliography}

Adamczyk J., 2017, The Accounting Act. Ustawa o rachunkowości, Wydawnictwo C.H. Beck, Warszawa.

Arkan T., 2015, The Effects of Earning Management Techniques, Net Income and Cash Flow on Stock Price, Zeszyty Naukowe Uniwersytetu Szczecińskiego nr 855: Finanse, Rynki Finansowe, Ubezpieczenia nr 74(2), Wydawnictwo Uniwersytetu Szczecińskiego, Szczecin.

Comporek M., 2016, Determinanty efektywności ekonomicznej aktywów obrotowych przemysłowych spółek giełdowych, Wydawnictwo Uniwersytetu Łódzkiego, Łódź.

DeAngelo L., 1986, Accounting numbers as market valuation substitutes: a study of management buyouts of public stockholders, The Accounting Review, vol. 61.

Dechow P.M., Skinner D.J., 2000, Earnings management: reconciling the views of accounting academics, practitioners, and regulators, Accounting Horizon, no. 14.

Dechow P., Sloan R.G., Sweeney A.P., 1995, Detecting earnings management, The Accounting Review, vol. 70(2).

Duraj A.N., 2008, Rezerwy a strategie finansowe publicznych spółek akcyjnych, Wydawnictwo Uniwersytetu Łódzkiego, Łódź.

Duraj N., Sosnowski T., 2015, Zabezpieczenie finansowe rezerwami bilansowymi działalności nowych spółek giełdowych, Studia Prawno-Ekonomiczne, t. XCVII, Łódzkie Towarzystwo Naukowe, Łódź.

Gmytrasiewicz M., 2001, Rezerwy w rachunkowości, Difin, Warszawa.

Healy P.M., Wahlen J.M., 1999, A review of the earnings management literature and its implications for standard setting, Accounting Horizons, no. 13(4).

Healy P.M., 1985, The effect of bonus schemes on accounting decisions, Journal of Accounting and Economics, vol. 7.

Jones J., 1991, Earnings management during import relief investigations, Journal of Accounting Research, vol. 29, no. 2.

Kang S., Sivaramakrishnan K., 1995, Issues in testing earnings management and an instrumental variable approach, Journal of Accounting Research, no. 33(2).

Kasznik R., 1999, On the association between voluntary disclosure and earnings management, Journal of Accounting Research, no. 37.

Kothari S.P., Leone A.L., Wasley C.E., 2005, Performance matched discretionary accrual measures, Journal of Accounting and Economics, vol. 39, no. 1.

Maszczak T., 2017, Rezerwy jako instrument kształtowania wyniku finansowego jednostki gospodarczej, Prace Naukowe Uniwersytetu Ekonomicznego we Wrocławiu, nr 272, Wydawnictwo Uniwersytetu Ekonomicznego we Wrocławiu, Wrocław.

${ }^{8}$ The search for new regression models, characterized by a higher explanatory power and reducing the risk of type II error should be one of the key areas of interest in research on the issue of earnings management [Zarowin 2015, pp. 5-6]. 
Ostasiewicz S., Rusnak Z., Siedlecka U., 2001, Statystyka. Elementy teorii i zadania, Wydawnictwo Akademii Ekonomicznej we Wrocławiu, Wrocław.

Poniatowska L., 2014, Polityka rachunkowości $w$ zakresie rezerw na zobowiazania i jej znaczenie w kształtowaniu wyniku finansowego, Studia Ekonomiczne, nr 201, Wydawnictwo Uniwersytetu Ekonomicznego w Katowicach, Katowice.

Poniatowska L., 2016, Rezerwy kapitałowe i ich znaczenie w działalności jednostki gospodarczej, Finanse, Rynki Finansowe, Ubezpieczenia, nr 2/2016 (80), Wydawnictwo Uniwersytetu Szczecińskiego, Szczecin.

Ronen J., Yaari V., 2008, Earnings Management, Springer Verlag.

Smejda M., 2012, Determinanty zarządzania zyskami, Studia Ekonomiczne, nr 125, Wydawnictwo Uniwersytetu Ekonomicznego w Katowicach, Katowice.

Walińska E., Bek-Gaik B., 2010, Rezerwy jako instrument ksztattujący wizerunek przedsiębiorstwa w sprawozdaniu finansowym $w$ dobie kryzysu gospodarczego, Uniwersytet Ekonomiczny w Krakowie, Kraków.

Walińska E., Bek-Gaik B., 2013, Rezerwy jako istotna kategoria kształtująca wynik finansowy spółek, Zeszyty Naukowe Uniwersytetu Szczecińskiego nr 698: Finanse, Rynki Finansowe, Ubezpieczenia nr 50, Wydawnictwo Uniwersytetu Szczecińskiego, Szczecin.

Zarowin P., 2015, Estimation of Discretionary Accruals and the Detection of Earnings Management, Oxford Handbooks Online, Oxford University Press.

Zbaraszewska A., 2011, Noty wykorzystywane przy sporządzaniu rachunku przeplywów pieniężnych metoda pośrednia, Zeszyty Naukowe Uniwersytetu Szczecińskiego nr 688: Finanse, Rynki Finansowe, Ubezpieczenia, nr 41, Wydawnictwo Uniwersytetu Szczecińskiego, Szczecin.

\section{ZWIĄZKI GOSPODAROWANIA REZERWAMI Z MEMORIALOWYMI KOREKTAMI ZYSKU NETTO - ODNIESIENIE DO PROBLEMATYKI ZARZĄDZANIA WYNIKIEM FINANSOWYM W SPÓŁKACH GIEŁDOWYCH}

Streszczenie: Zasadniczym celem opracowania jest zbadanie związków zachodzących między realizowaną polityką tworzenia i rozwiązywania rezerw a wartościami memoriałowych korekt zysku netto wykazywanych w sprawozdaniach finansowych spółek giełdowych notowanych na rynku głównym GPW w Warszawie. Obie wskazane sfery badawcze traktowane są jako główne obszary kreacji wyniku finansowego, który można postrzegać zarówno jako dążenie do urealnienia sytuacji finansowej podmiotu gospodarczego zgodnie z zasadą true and fair view, jak i intencjonalne manipulowanie osiąganymi rezultatami działalności gospodarczej w celu wprowadzenia w błąd wybranych interesariuszy jednostki. Badanie empiryczne przeprowadzone zostało wśród przedsiębiorstw publicznych wchodzących w skład indeksów giełdowych: WIG20, mWIG40 i sWIG80, których akcje były przedmiotem obrotu na giełdzie przez co najmniej 10 lat w przyjętym horyzoncie lat 1997-2016.

Słowa kluczowe: rezerwy, korekty zysku netto, zarządzanie zyskiem, wynik finansowy. 